\title{
RELATIONSHIP BETWEEN KNOWLEDGE AND FAMILY SUPPORT REGARDING HYPERTENSION WITH BLOOD PRESSURE CONTROL IN ELDERS
}

\author{
Iin Kusumawardana1), Didik Gunawan Tamtomo²), Sugiarto3) \\ 1) Masters Program of Family Medication, Sebelas Maret University \\ 2) Faculty of Medicine, Sebelas Maret University \\ 3) Science of Internal Disease Sub Metabolic Endocrine and Diabetes, Dr. \\ Moewardi Hospital, Surakarta
}

\begin{abstract}
Background: Hypertension is one of the degenerative diseases that have frequently been found among the group of elders. If hypertension goes uncontrolled, then it might escalate and cause complication. The level of knowledge for both of patients and their families in terms of preventive actions toward hypertension complication is expected to be able to control blood pressure. Among the hypertension patients, the role of family support is very important in order to maintain and to control that the blood pressure will not increase and to return it to the normal state. In relation to this background, the objective in conducting this study was to analyze the relationship between knowledge and family support regarding hypertension with blood pressure control among the elders with hypertension in the Sangkrah Center of Public Health, City of Surakarta.

Subjects and Method: This was an analytic observational study with cross sectional design. This study was conducted in Sangkrah Community Health Center in the City of Surakarta on November 2016. A total sample of 147 elders were selected for this study by purposive sampling. The dependent variable in this study was blood pressure and was measured by sphygnomanometer. The independent variables were knowledge and family support and were collected by a set of questionnaire. The data analyzed by logistic regression.
\end{abstract}

Results: Family knowledge $(\mathrm{OR}=0.38 ; 95 \% \mathrm{CI}=0.13$ to $1.08 ; \mathrm{p}=0.070)$ increased the likelihood of blood pressure control. Elders who came from family with good knowledge regarding hypertension had 0.4 times better blood pressure control in comparison to those who came from family with poor knowledge regarding hypertension. Family support $(\mathrm{OR}=0.43 ; 95 \% \mathrm{CI}=$ 0.18 to $1.02 ; \mathrm{p}=0.046$ ) increased the likelihood of blood pressure control. Elders with good family support had 0.4 times better blood pressure than those who had poor family support.

Conclusion: Family knowledge and family support increase the probability of blood pressure control among elders with hypertension.

Keywords: knowledge, family support, blood pressure control, elders

Correspondence: Iin Kusumawardana. Masters Program in Public Health, Sebelas Maret University, Jl. Ir. Sutami 36 A, Surakarta 57126, Central Java, Indonesia. Email: iinkusuma9o@gmail.com 